\title{
THE EFFECT OF HEMP ESSENTIAL OIL ON MORTALITY Aulacorthum solani Kalt. AND Tetranychus urticae Koch
}

\author{
WPŁYW OLEJKU ETERYCZNEGO Z KONOPI NA ŚMIERTELNOŚĆ \\ Aulacorthum Solani Kalt. I Teranychus urticae Koch
}

\begin{abstract}
Investigations concerning the effect of hemp oil on mortality of the foxglove aphid (Aulacorthum solani Kalt.) and the two spotted spider mite (Tetranychus urticae Koch) were conducted in the years 2014-2015. The tested essential oil was produced at the Institute of Natural Fibers and Medicinal Plants in Poznan. It was obtained by steam distillation of fresh panicles of Polish hemp cultivars, Beniko, Bialobrzeskie and Silesia, with low cannabinoid contents, including THC (max. 0.2\% plant fresh matter). The effect of essential oil on the investigated pests was determined following the application of aqueous emulsion solution at $0.02,0.05$ and $0.1 \%$. Mortality of agrophages was determined 24, 48 and $72 \mathrm{~h}$ after treatment. In this study a very high efficacy of the essential oil produced from hemp panicles was found in the reduction of population size of the foxglove aphid (A. solani). Already at $24 \mathrm{~h}$ after its application at a concentration of $0.1 \%$ pest mortality rate was $98.20 \%$, while after $48 \mathrm{~h}$ it reached $100 \%$. A significant, although much lesser effect of oil on the aphid population was recorded when applying it at $0.05 \%$, with the mortality rate of the true bug after $72 \mathrm{~h}$ amounting to $57.33 \%$. Essential oil also showed an effect on the two spotted spider mite (T. urticae). Following the oil application, irrespective of its concentration, a significant effect on mite mortality was observed. Its action was the strongest at its highest concentration, ie $0.1 \%$, while mortality of the pest at 24,48 and $72 \mathrm{~h}$ after treatment was $83.28,95.83$ and $98.72 \%$, respectively.
\end{abstract}

Keywords: natural essential oil, Cannabis sativa L., mortality, foxglove aphid (A. solani Kalt.), two spotted spider mite (T. urticae Koch)

\section{Introduction}

In recent years we have been observing an increased interest in growing hemp as a crop for industrial applications. EU subsidies have made commercial hemp growing exceptionally profitable. As a result the area cropped to hemp has increased from 80 ha in 2003 to 4.8 thousand ha in 2015. However, the dynamic increase in the area of hemp culture is also connected with the problem of hemp panicle management, currently either

\footnotetext{
${ }^{1}$ Department of Entomology and Environmental Protection, Poznań University of Life Sciences, ul. Zgorzelecka 4, 60-198 Poznań, Poland

${ }^{2}$ Department of Vegetable Crops, Poznań University of Life Sciences, ul. Dąbrowskiego 159, 60-594 Poznań, Poland

*Corresponding author: rgorski@up.poznan.pl
} 
used as fuel material or considered to be a useless waste. The new mechanical harvest technology of hemp, developed at the Institute of Natural Fibres and Medicinal Plants in Poznan, facilitates separate harvest of panicles, from which essential oil may be extracted by steam distillation. In this way it is possible to obtain additionally essential oil from hemp, which may be used to a greater extent to produce cosmetics or foodstuffs, including alcohol [1-3]. Hemp essential oil may also be used in plant protection thanks to its contents of numerous chemicals, of which some exhibit high activity against pests. As it was reported by Turner et al [4] and Ross and Elsohly [5], this essential oil may contain as many as 58 monoterpenes and 38 sesquiterpenes. Contents of monoterpenes are much higher than those of sesquiterpenes and depending on hemp cultivar and time of harvest may range from 47.9 to $92.1 \%$ total terpene contents. Contents of sesquiterpenes range from 5.2 to $48.6 \%$ total terpene contents. As it was reported by Mediavilla and Steinemann [6], particularly two terpenes contained in hemp essential oil act strongly on pests, ie limonene and $\alpha$-pinene, while Pate [7], apart from the above mentioned, also recorded activity of such terpenes as $\beta$-pinene, terpineol and borneol.

At present extensive studies are being conducted on the application of natural origin preparations, including essential oils obtained from various plant species, in plant protection. These studies are considered to be a priority, since an increasing number of chemical pesticides is being withdrawn, as the chemicals they contain are classified by the EU as particularly dangerous for human health and the natural environment [8]. Thus it is necessary to search for new, alternative methods of pest control.

The aim of this study was to evaluate the effect of essential oil obtained from panicles of hemp (Cannabis sativa L.) on mortality of the foxglove aphid (Aulacorthum solani Kalt.) and two spotted spider mite (Tetranychus urticae Koch).

\section{Materials and methods}

Investigations on the effect of hemp oil on mortality of the foxglove aphid (Aulacorthum solani Kalt.) and the two spotted spider mite (Tetranychus urticae Koch) were conducted in the years 2014-2015 at the Department of Entomology and Environmental Protection, the Poznan University of Life Sciences, Poland. The tested essential oil was produced at the Institute of Natural Fibres and Medicinal Plants in Poznan. It was obtained from fresh panicles of Polish hemp cultivars Beniko, Bialobrzeskie and Silesia, with low cannabinoid contents, including THC (max. $0.2 \%$ plant dry matter). These cultivars meet the requirements specified in the Act of 29 July 2005 on prevention of drug abuse [9] and they are certified for cultivation in Poland. Essential oil was produced by steam distillation of plant material using demineralised technological water. After purification the produced essential oil was put in dark containers of brown soda-lime glass protecting the product against the adverse effect of sunlight. It needs to be stressed that hemp panicles were harvested at the optimal stage of maturity in order to ensure adequate quality of essential oil. Chemical analysis of hemp essential oil was performed at the Institute of Natural Fibres and Medicinal Plants in Poznan using gas chromatography based on terpene standards (SIGMA-ALDRICH). Terpene contents were determined using a GC gas chromatograph by Perkin Elmer Autosystem XL, equipped with a SPB-5 column (SUPELKO) of $30 \mathrm{~cm}$, inner diameter of $0.32 \mathrm{~mm}$ (film $-0.25 \mu \mathrm{m}$ ) and a FID detector. Distillation was run maintaining the following parameters: injector temperature $220^{\circ} \mathrm{C}$, detector temperature $260^{\circ} \mathrm{C}$, oven temperature programme $60-240^{\circ} \mathrm{C}\left(3^{\circ} \mathrm{C} / \mathrm{min}\right)$, programme 
time $52.6 \mathrm{~min}$, carrier gas pressure (helium) $13.3 \mathrm{psi}$, injection rate $1 \mathrm{~mm}^{3}$, split 1:50. Contents of identified terpenes in the tested hemp essential oil are presented in Table 1 . The data show that among the analysed terpenes the following were found in considerable amounts: trans-caryophyllene at $35.58 \%, \beta$-myrcene $18.45 \%, \alpha$-pinene $9.76 \%$, terpinolene $7.40 \%$ and ocimene at $6.38 \%$.

Table 1

Contents of terpenes in tested hemp essential oils

\begin{tabular}{|c|c|c|}
\hline \multicolumn{2}{|c|}{ Component } & $\begin{array}{c}\text { Contents terpenes in } \\
\text { essential oil [\%] }\end{array}$ \\
\hline & $\alpha$-pinene & $\mathbf{9 . 7 6}$ \\
& camphene & 0.16 \\
& $\beta$-pinene & 4.03 \\
& $\beta$-myrcene & $\mathbf{1 8 . 4 5}$ \\
& $\alpha$-phelandrene & 0.25 \\
Monoterpenes & 3-carene & 0.29 \\
& limonene & 2.07 \\
& 1,8 -eucalyptol & 0.23 \\
& ocimene & $\mathbf{6 . 3 8}$ \\
& sabinene hydrate & 0.06 \\
& terpinolene & $\mathbf{7 . 4 0}$ \\
& linalool & 0.10 \\
& fenchol & 0.06 \\
& borneol & 0.03 \\
& bornyl acetate & 0.04 \\
\hline \multirow{2}{*}{ Sesquiterpenes } & trans-caryophyllene & $\mathbf{3 5 . 5 8}$ \\
& $\alpha$-humulene & 0.03 \\
& $\alpha$-humulene & 9.05 \\
& trans- $\beta$-farnesene & 3.99 \\
& caryophyllene oxide & 2.28 \\
\hline
\end{tabular}

Prior to observations the tested pest species were propagated on selected host species grown in containers. The foxglove aphid (A. solani) was propagated on eggplant cv. Epic, while two spotted spider mite ( $T$. urticae) was propagated on dwarf bean cv. Zlota Saxa. Leaves of the above-mentioned plants infested by tested pests were removed from plants and immersed for $3 \mathrm{~s}$ in the prepared solution (water emulsion) containing different concentrations of hemp oil, ie $0.02,0.05$ and $0.10 \%$. After leaves were removed from the solution they were placed for several seconds in the vertical position for excess liquid to drip down. In order to obtain a homogenous emulsion an emulsifier, RO-1, was added to solutions of tested oils at a concentration of $0.0125 \%$. In the conducted experiments the effect of the emulsifier RO-1 on mortality of the foxglove aphid and the two spotted spider mite was also tested by treating the pests with its solution at the applied concentration. In the control combination leaves infested by the investigated pests were immersed in water with no hemp oil added. Each combination was performed in 10 replications. After the essential oil was spread, leaves were placed on glass dishes lined with moistened filter paper and next plastic plates with holes of $35 \mathrm{~mm}$ in diameter were placed on leaf surface. The number of pests was counted in the location of holes in these plates. After counting was completed, plates with holes were covered with glass plates, constituting a physical barrier preventing migration of bugs and spiders. Filter paper was moistened with water daily in order to maintain leaf turgor. 
The effect of hemp oil applied at different concentrations on mortality of $A$. solani and T. urticae was determined after 24,48 and $72 \mathrm{~h}$. Results were analyzed statistically using the Newman-Keuls test at the significance level $p=0.05$.

\section{Results and discussion}

Conducted experiments showed a very high efficacy of the essential oil produced from hemp panicles in the control of the population of the foxglove aphid (A. solani) (Table 2). Already at $24 \mathrm{~h}$ after its application at a concentration of $0.1 \%$ mortality rate of the pest was $98.20 \%$, while after $48 \mathrm{~h}$ it reached $100 \%$. A significant, although much lesser effect of the oil on the population size of the aphid was recorded when it was applied at a concentration of $0.05 \%$. In that combination mortality rate of the true bug after $72 \mathrm{~h}$ was $57.33 \%$. No significant effect of hemp oil was found on survival rates of the foxglove aphid at its application at the lowest concentration $(0.02 \%)$. In those experiments no effect of the emulsifier RO-1 applied at $0.0125 \%$ was observed on the population size of the foxglove aphid. No significant differences were found in mortality rates of this pest treated with the emulsifier solution in comparison to the control.

Average mortality of foxglove aphid (Aulacorthum solani Kalt.) on eggplant after application of natural essential hemp oil

\begin{tabular}{|c|c|c|c|c|}
\hline \multirow{2}{*}{ Treatment } & \multirow{2}{*}{$\begin{array}{c}\text { Concentration } \\
{[\%]}\end{array}$} & \multicolumn{3}{|c|}{ No. of hours after treatment } \\
\cline { 2 - 4 } & & 24 & 48 & 72 \\
\cline { 2 - 4 } & 0.02 & $22.34 \mathrm{a}$ & $27.53 \mathrm{a}$ & $23.87 \mathrm{a}$ \\
\hline \multirow{3}{*}{ Cannabis oil } & 0.05 & $29.42 \mathrm{a}$ & $25.90 \mathrm{a}$ & $57.33 \mathrm{~b}$ \\
\cline { 2 - 5 } & 0.10 & $98.20 \mathrm{~b}$ & $100.00 \mathrm{~b}$ & $100.00 \mathrm{c}$ \\
\cline { 2 - 5 } & 0.0125 & $40.27 \mathrm{a}$ & $52.43 \mathrm{a}$ & $47.47 \mathrm{ab}$ \\
\hline Emulsifier RO-1 & - & $27.92 \mathrm{a}$ & $39.15 \mathrm{a}$ & $58.45 \mathrm{~b}$ \\
\hline Control & &
\end{tabular}

Means in columns denoted with identical letters do not differ significantly $(p=0.05)$ according to the Newman-Keuls test

Average mortality of two spotted spider mite (Tetranychus urticae Koch) on bean after application of natural essential hemp oil

\begin{tabular}{|c|c|c|c|c|}
\hline \multirow{2}{*}{ Treatment } & \multirow{2}{*}{$\begin{array}{c}\text { Concentration } \\
{[\%]}\end{array}$} & \multicolumn{3}{|c|}{ No. of hours after treatment } \\
\cline { 2 - 4 } & & \multicolumn{3}{|c|}{ mortality [\%] } \\
\cline { 2 - 4 } & 0.02 & $43.55 \mathrm{a}$ & $60.31 \mathrm{~b}$ & $71.14 \mathrm{a}$ \\
Cannabis oil & 0.05 & $66.63 \mathrm{ab}$ & $71.40 \mathrm{~b}$ & $79.80 \mathrm{a}$ \\
& 0.10 & $83.28 \mathrm{~b}$ & $95.83 \mathrm{c}$ & $98.72 \mathrm{~b}$ \\
\hline Emulsifier RO-1 & 0.0125 & $46.57 \mathrm{a}$ & $66.24 \mathrm{~b}$ & $77.88 \mathrm{a}$ \\
\hline Control & - & $37.59 \mathrm{a}$ & $47.56 \mathrm{a}$ & $69.66 \mathrm{a}$ \\
\hline
\end{tabular}

Means in columns denoted with identical letters do not differ significantly $(p=0.05)$ according to the Newman-Keuls test

Essential oil produced from hemp panicles exhibited its effect also on the other investigated pest, the two spotted spider mite (T. urticae) (Table 3). Following the application of this oil, irrespective of its concentration, a significant effect on mite mortality was recorded. The strongest effect was observed at its highest concentration, ie $0.1 \%$, with 
pest mortality rates at 24,48 and $72 \mathrm{~h}$ after treatment amounting to $83.28,95.83$ and $98.72 \%$. Similarly as in the case of the foxglove aphid, treatment of the two spotted spider mite with a solution of the RO-1 emulsifier had no significant effect on the population size of this pest.

Literature sources published in other countries contain fragmentary information on the effect of different parts of hemp plants and extracts obtained from this plant on the populations of pests.

Grewal [10] reported a toxic action of dried hemp leaves on Aphelenchoides composticola (Franklin), ie a nematode infesting cultivated mushrooms. The leaves were added to the compost used in the production of garden mushroom (Agaricus bisporus /Lange/ Imbach). Dried leaves may also exhibit a repellent action on pests, eg those found in grain silos such as the wheat weevil (Sitophilus granarius L.) and the rice weevil (Sitophilus oryzae L.) $[11,12]$, while when placed under a bed mattress protected against bed bugs (Cimex lectularius L.) [12].

Hemp seeds may also prove useful in plant protection. Goswami and Vijayalakshmi [13] reduced the population of the root-node nematode (Meloidogyne incognita Kofoid \& White) in tomato culture after supplementation of substrate with hemp seeds.

In other studies Rothschild et al [14] recorded high mortality in larvae of the garden tiger moth (Arctia caja L.) fed hemp shoots.

Strong toxic properties in relation to pests were also observed for aqueous and alcohol hemp extracts. Their strong action was also reported in relation to the Colorado beetle (Leptinotarsa decemlineata Say), two spotted spider mite (Tetranychus urticae Koch) [12], larvae of mosquitoes from the genus Anopheles transmitting malaria [15] as well as nematodes, eg Heterodera cajani Koshy, Hoplolaimus indicus Sher, Rotylenchulus reniformis Linford \& Oliveira, Tylenchorynchus brassicae Siddiqi [16].

Hemp extracts not only exhibit a toxic action on pests, but also show repellent properties. Researchers observed the repellent effect of hemp extracts towards the large white (Pieris brassicae L.) and the Japanese beetle (Popillia japonica Newman) [12, 17]. It was also found that hemp growing in the vicinity of various cultures has a repellent action on pests colonizing them, eg the large white (Pieris brassicae L.) in vegetable growing, the Colorado beetle (Leptinotarsa decemlineata Say) on potatoes, the wheat white fly (Delia coarctata Fallen) on wheat [12]. Mateeva [18] showed that chemicals secreted by hemp roots repel larvae of the May beetle (Melolontha melolontha L.) developing in the substrate. They may also inhibit the development of pest populations attacking underground parts of plants, as it was found in the case of nematodes: the golden nematode (Globrodera rostochiensis Wollenweber) [12], the soybean cyst nematode (Heterodera glycines Ichinohe) [19], or columbia root-knot nematode (Meloidogyne chitwoodi Golden, O'Bannon, Santo \& Finley) [20].

The above examples of the effect of hemp on pests did not refer to the action of essential oil produced from this plant. So far a limited number of studies have been conducted on the applicability of hemp essential oil in plant protection. In an earlier publication one of the authors of this paper [21] showed high efficacy of essential oil obtained from hemp panicles in the control of the rosy apple aphid (Dysaphis plantaginea Pass.) on apple trees. At $24 \mathrm{~h}$ after the treatment $93 \%$ mortality of this pest was reported, similarly as it was the case of the application of a phosphorus organic pesticide Mospilan 20 SP. 
In other studies Pavela [22] reported marginal insecticidal activity of hemp essential oil against mosquito (Culex quinquefasciatus Say) larvae. The major component in the hemp oil, (E)-caryophyllene has shown only limited activity against Aedes aegypti (L.) [23], Rhyzopertha dominica (F.), Sitophilus oryzae (L), Tribolium castaneum (Herbst) [24] or Lycoriella ingenua (Dufour) [25].

Some studies discovered that essential hemp oil demonstrated antibacterial and antifungal activity [26-30].

\section{Conclusions}

- $\quad$ Essential oil produced from panicles of hemp (Cannabis sativa L.) may be suitable in pest control.

- High mortality rates of the foxglove aphid (Aulacorthum solani Kalt.) and the two spotted spider mite (Tetranychus urticae Koch) were recorded following the application of hemp essential oil in the solution of aqueous emulsion.

- Efficacy of hemp essential oil was dependent on its concentration. Mortality rates of the analysed pests increased with an increase in its concentration in the emulsion solution.

- It is recommended to use hemp oil in a concentration of $0.1 \%$. With such a concentration of the essential oil was found the highest mortality of investigated pests.

\section{References}

[1] Ranalli P, Ventyri G. Hemp as a raw material for industrial application. Euphytica. 2004;140(1):1-6. DOI: 10.1007/s10681-004-4749-8.

[2] Vogl CR, Mölleken H, Lissek-Wolf G, Surböck A, Kobert J. Hemp (Cannabis sativa L.) as resource of green cosmetics: Yield of seed and fatty acid compositions of 20 varieties under the growing conditions of organic farming in Austria. Journal of Industrial Hemp. 2004;9(1):51-68. DOI: 10.1300/J237v09n01_06.

[3] Zaikov GE, Pudel DP, Spychalski G. Renewable Resources and Biotechnology for Material Application. Materials Sciences and Technologies. New York: Nova Science Publishers, Inc.; 2011. https://www.197.14.51.10:81/pmb/AGROALIMENTAIRE/1612095216RenewableB.pdf.

[4] Tuner CE, El Sohly MA, Boeren EG. Constituents of Cannabis sativa L. XVII. A review of the natural constituents. J Nat Prod. 1980;43(2):169-234. DOI: 10.1021/np50008a001.

[5] Ross SA, El Sohly MA. The volatile oil composition of fresh and air-dried buds of Cannabis sativa. J Nat Prod. 1996;59(1):49-51. DOI: 10.1021/np960004a.

[6] Mediavilla V, Steinemann S. Essential oil of Cannabis sativa L. strains. J Int Hemp Assoc. 1997;4(2):80-82. http://www.internationalhempassociation.org/jiha/jiha4208.html.

[7] Pate DW. Chemical ecology of Cannabis. J Int Hemp Assoc. 1994;1(2):32-37. http://www.hempfood.com/IHA/iha01201.html.

[8] Directive of the EEC Council of 15.07.1991, consolidated version of 01.08.2006, on the marketing of plant protection products - 91/414/EEC). http://demo.eurocases.eu/Doc/CourtAct/4435312.

[9] Ustawa z dnia 29 lipca 2005 r. o przeciwdziałaniu narkomanii. DzU 2005.179.1485 z dnia 19 września 2005 r. [Act of 29 July 2005 on prevention of drug abuse, the Journal of Laws 2005.179.1485, of 19 September 2005]. http://www.kbpn.gov.pl/portal?id=15\&res_id=493734.

[10] Grewal PS. Effect of leaf-matter incorporation on Aphelenchoides composticola (Nematoda), mycofloral composition, mushroom compost quality and yield of Agaricus bisporus. Ann Appl Biol. 1989;115:299-312. DOI: $10.1111 / \mathrm{j} .1744-7348.1989$.

[11] Khare BP, Gupta SB, Chandra S. Biological efficacy of some plant materials against Sitophilus oryzae L. Indian J Agric Res. 1974;8:243-248. https://books.google.pl/books?isbn=0851994547.

[12] MacPortland JM. Cannabis as repellent and pesticide. J Int Hemp Assoc. 1997;4(2):87-92. http://www.druglibrary.net/olsen/HEMP/IHA/jiha4210.html. 
[13] Goswami BK, Vijayalakshmi K. Efficacy of some indigenous plant materials and oil cake amended soil on the growth of tomato and root-knot nematode population. Ann Agric Res. 1986;7(2):263-266. https://books.google.pl/books?isbn=9401141738.

[14] Rothschild M, Rowan MR, Fairbairn JW. Storage of cannabinoids by Arctia caja and Zonocerus eleganns fed on chemically distinct strains of Cannabis sativa. Nature. 1977;266:650-651. https://books.google.pl/books?isbn=0851994547.

[15] Jalees S, Sharma SK, Rahman SJ, Verghese T. Evaluation of insecticidal properties of an indigenous plant, Cannabis sativa L. against mosquito larvae under laboratory conditions. J Entomol Res. 1993;17:117-120. http://www.indianjournals.com/ijor.aspx?target=ijor:jer\&volume $=17 \& i s s u e=2 \&$ article $=007$.

[16] Mojumder V, Mishra SD, Haque MM, Goswami BK. Nematicidal efficacy of some wild plants against pigeon pea cyst nematode Heterodera cajani. Int Nematol Network Newsletter. 1989;6(2):21-24. https://www.cabdirect.org/cabdirect/abstract/19901138060.

[17] Rothschild M, Fairbairn JW. Ovipositing butterfly (Pierris brassicae L.) distinguishes between aqueous extracts of two strains Cannabis sativa L. and THC and CBD. Nature. 1980;286:56-59. DOI: $10.1038 / 286056 \mathrm{a} 0$.

[18] Mateeva A. Use of unfriendly plants against root knot nematodes. Acta Hort. 1995;382:178-182. DOI: 10.17660/ActaHortic.1995.382.19.

[19] Scheifele G, Dragla P, Pinsonneault C, Laprise M. Hemp (Cannabis sativa) research report. Kent Country, Ontario, Canada. Ridgetown College of Agricultural Technology;1996. http://documents.mx/documents/ hemp-nationalindustrialhempstrategyfinalcomplete2.html.

[20] Kok CJ, Coenen GCM, De Heij A. The effect of fibre hemp (Cannabis sativa L.) on selected soil-borne pathogens. J Int Hemp Assoc. 1994;1(1):6-9. http://www.druglibrary.net/olsen/HEMP/IHA/iha01103.html.

[21] Górski R, Szklarz M, Kaniewski R. Skuteczność olejku eterycznego z konopi siewnej w zwalczaniu mszycy jabłoniowo-babkowej (Dysaphis plantaginea Pass.) występującej na jabłoni. [Efficacy of hemp essential oil in the control of rosy apple aphid (Dysaphis plantaginea Pass.) occurring on apple tree]. Prog Plant Prot./Post Ochr Roślin. 2009;49(4):2013-2016. https://pbn.nauka.gov.pl/polindex-webapp/browse/article/articlef129d711-d10c-4930-8605-67b6b0f91694.

[22] Pavela R. Larvicidal property of essential oils against Culex quinquefasciatus Say (Diptera: Culicidae). Ind Crop Prod. 2009;30:311-315. DOI: 10.1016/j.indcrop.2009.06.005

[23] Silva WJ, Dória GAA, Maia RT, Nunes RS, Carvalho GA, Blank AF, et al. Effects of essential oils on Aedes aegypti larvae: Alternatives to environmentally safe insecticides. Bioresource Technol. 2008;99:3251-3255. DOI: 10.1016/j.biortech.2007.05.064.

[24] Zeng L, Lao CZ, Cen YJ, Liang GW. Study on the insecticidal activity compounds of the essential oil from Syzygium aromaticum against stored grain insect pests. Proceedings of the 10th International Working Conference on Stored Product Protection - 27 June to 2 July 2010, Estoril, Portugal. Julius-Kühn-Archiv. 2010;425:766-771. DOI: 10.5073/jka.2010.425.237.

[25] Park IK, Kim JN, Lee YS, Lee SG, Ahn YJ, Shin SC. Toxicity of plant essential oils and their components against Lycoriella ingenua (Diptera: Sciaridae). J Econ Entomol. 2008;101(1):139-144. DOI: 10.1093/jee/101.1.139.

[26] Fournier G, Paris MR, Fourniat MC, Quero AM. Bacteriostatic activity of Cannabis sativa L. essential oil. Ann Pharm Fr. 1978;36(11-12):603-606. http://www.ncbi.nlm.nih.gov/pubmed/754639.

[27] Cowan MM. Plant products as antimicrobial agents. Clin Microbiol Rev. 1999;12:564-582. http://www.ncbi.nlm.nih.gov/pubmed/10515903.

[28] Novak J, Zitterl-Eglseer K, Deans SG, Franz CM. Essential oils of different cultivars of Cannabis sativa L. and their antimicrobial activity. Flavour Frag J. 2001;16:259-262. DOI: 10.1002/ffj.993.

[29] Radwan MM, El Sohly MA, Slade D, Ahmed SA, Khan IA, Ross SA. Biologically active cannabinoids from high-potency Cannabis sativa. J Nat Prod. 2009;72(5):906-911. DOI: 10.1021/np900067k.

[30] Nissen L, Zatta A, Stefanini I, Grandi S, Sgorbati B, Biavati B, Monti A. Characterization and antimicrobial activity of essential oils of industrial hemp varieties (Cannabis sativa L.). Fitoterapia. 2010;81:413-419. DOI: 10.1016/j.fitote.2009.11.019. 